\title{
Retraction Note: Flavonoids modulate multidrug resistance through wnt signaling in P-glycoprotein overexpressing cell lines
}

\author{
S. Mohana', M. Ganesan', N. Rajendra Prasad ${ }^{1 *}$, D. Ananthakrishnan² and D. Velmurugan 2,3
}

\section{Retraction Note: BMC Cancer 18, 1168 (2018)}

https://doi.org/10.1186/s12885-018-5103-1

The editor has retracted this article [1]. Concerns were raised regarding a number of figures, specifically:

- Figure 2: the FZD1 blots in panels e (Rutin experiment) and $f$ (Epicatechin experiment) appear to be identical.

- Figure $4 \mathrm{~b}$ and $\mathrm{c}$ appear to be identical.

- Figure $4 \mathrm{~d}$ and $\mathrm{f}$ appear to be very similar.

- Figure $4 \mathrm{i}$ and $\mathrm{l}$ appear to be very similar.

The data reported in this article are therefore unreliable. M. Ganesan, N. Rajendra Prasad, D. Ananthakrishan and D. Velmurugan agree with this retraction. S. Mohana has not responded to correspondence regarding this retraction.

\section{Author details}

'Department of Biochemistry and Biotechnology, Annamalai University, Annamalai Nagar, Tamil Nadu 608 002, India. ${ }^{2}$ Bioinformatics Infrastructure Facility (BIF), University of Madras, Guindy Campus, Chennai, Tamil Nadu, India. ${ }^{3}$ CAS in Crystallography and Biophysics, University of Madras, Guindy Campus, Chennai, Tamil Nadu, India.

Published online: 11 February 2021

\section{Reference}

1. Mohana S, Ganesan M, Rajendra Prasad N, et al. Flavonoids modulate multidrug resistance through wnt signaling in P-glycoprotein overexpressing cell lines. BMC Cancer. 2018;18:1168. https:/doi.org/10.1186/s12885-018-5103-1.

The original article can be found online at https://doi.org/10.1186/s12885018-5103-1.

* Correspondence: drprasadnr@gmail.com

${ }^{1}$ Department of Biochemistry and Biotechnology, Annamalai University, Annamalai Nagar, Tamil Nadu 608 002, India

Full list of author information is available at the end of the article

C C The Author(s). 2021 Open Access This article is licensed under a Creative Commons Attribution 4.0 International License, which permits use, sharing, adaptation, distribution and reproduction in any medium or format, as long as you give appropriate credit to the original author(s) and the source, provide a link to the Creative Commons licence, and indicate if changes were made. The images or other third party material in this article are included in the article's Creative Commons licence, unless indicated otherwise in a credit line to the material. If material is not included in the article's Creative Commons licence and your intended use is not permitted by statutory regulation or exceeds the permitted use, you will need to obtain permission directly from the copyright holder. To view a copy of this licence, visit http://creativecommons.org/licenses/by/4.0/. The Creative Commons Public Domain Dedication waiver (http://creativecommons.org/publicdomain/zero/1.0/) applies to the data made available in this article, unless otherwise stated in a credit line to the data. 